DOI: https://doi.org/10.32839/2304-5809/2020-12-88-28

УДК 338

Кошова Б.Р.

Національний університет «Львівська політехніка»

\title{
КОНКУРЕНТОСПРОМОЖНІСТЬ ТУРИСТИЧНОЇ СФЕРИ РЕГІОНІВ УКРАЇНИ
}

\begin{abstract}
Анотація. У статті проведено дослідження конкурентоспроможності туристичної сфери областей України. Враховуючи поліструктурність туризму, як явища, методика оцінювання містить ключові елементи, котрі формують відповідний субіндекс, котрий складається із історико-культурних, природних, транспортних та туристичних показників. Якість транспортної складової проаналізовано за показниками обсягів наданих послуг залізничним, авіаційним та автобусним транспортом. Туристичну сферу оцінено за кількістю закладів харчування та розміщення. Як ключовими елементами конкурентоспроможності сфери туризму певної території виділена кількісна характеристика наявних історико-культурних пам'яток та різноманітних об’єктів природно-заповідного фонду. Проведений аналіз дає змогу наочно відобразити конкурентоспроможність кожної із областей України та виявити недоліки у забезпеченні туристичного обслуговування.
\end{abstract}

Ключові слова: туристична сфера, області України, конкурентоспроможність, транспортна інфраструктура, історико-культурні ресурси, природні ресурси.

Koshova Bohdana

Lviv Polytechnic National University

\section{COMPETITIVENESS OF THE TOURIST SPHERE OF THE REGIONS OF UKRAINE}

Summary. The article examines the competitiveness of the tourism sector in Ukraine. The study was based on the calculation of the competitiveness sub-index, which was proposed to be calculated on the basis of identified key indicators of tourism quality. Namely: the quality of land and air transport infrastructure, the quality of food and accommodation, the quality of historical and cultural, natural resources and information and telecommunications technologies. Based on the calculated indicators, the limits were set, according to which we can say about the competitiveness of each of the regions of Ukraine in the field of tourism. The technique given by us suggests to accept limits from 0,01 to 0,1 and above. Where the value of the sub-index is less than $0.05-$ will characterize the competitiveness of the tourism sector of Ukraine as low. The sub-index at the level of 0.051 to 0.1 - will characterize the competitiveness of the tourism sector as average. The level of the indicator is higher than 0.1 - will characterize the competitiveness of the tourist sphere of the region as high. The indicator was also calculated separately for the city of Kyiv. This is due to the fact that the capital is the main generator of business flows to the state, where more than 2.8 million people live. For thousands of years, all state authorities have been concentrated here, which has led to the formation of a unique historical and cultural heritage that will always attract tourists from around the world. Using statistical and analytical data from official sources, in accordance with our proposed methodology, it was found that only the Lviv region and the city of Kyiv have a high competitiveness in the field of tourism in Ukraine. Dnipropetrovsk, Odesa, Kyiv, Kharkiv and Zaporizhia oblasts demonstrate the average. The reason for the low competitiveness of most regions is the lack of developed transport links. Low demand for rail transport among the local population and among tourists is due to outdated rolling stock, which is not able to provide quality service to travelers. Lack of proper quality roads, imperfection of information and telecommunication technologies, insufficient funding in the field of preservation of historical and cultural monuments and promotion of their value at the state level, low level of environmental protection - all this has a negative impact on the tourist attractiveness.

Keywords: tourist sphere, regions of Ukraine, competitiveness, transport infrastructure, historical and cultural resources, natural resources.

Постановка проблеми. Конкурентоспроможність в туризмі являе собою складне, багатогранне поняття. Адже, для того щоб туристична індустрія певної країни чи окремо взятої дестинації, була конкурентоспроможною необхідно не лише розвинений туристичний сектор, а й наявність високоякісних супутніх галузей охорони здоров'я, інформаційної, транспортної та ін. Значне різноманіття історико-культурних пам'яток, рекреаційних ресурсів, привабливих природних ландшафотів не є запорукою успішності розвитку туризму. Транспортна доступність, безпека та соціальна захищеність, розвинена медична та інформаційна сфери, привітність місцевого населення у сукупності із туристично привабливими ресурсами та розвиненою туристичною інфраструктурою є визначальними чинниками у обранні туристичного напряму.
Усі регіони України, без виключення, можуть достойно представити на світовій арені самобутню культуру, історико-архітектурні цінності, унікальне природне багатство, але лише деякі із них зуміли створити конкурентоспроможний туристичний продукт, котрий приваблюе не лише внутрішніх туристів, а і зовнішніх. Оцінювання ключових елементів конкурентоспроможності туристичної сфери дасть змогу не лише провести рангове оцінювання, а й встановити причини такого стану.

Аналіз останніх досліджень і публікацій. Дослідження конкурентоспроможності туристичної сфери України висвітлено у багатьох наукових працях, переважна більшість котрих спираеться на методику UNWTO відповідно до Рапорту конкурентоспроможності подорожей i туризму. Із ціеї точки зору дослідження проведено у Смир- 
нова І.Г., Шикіна О.В., Полковниченко С.О., Красія А.В., Михайленко Т.I., котрі вказують на місце вітчизняної туристичної сфери у світовому співтоваристві. Регіональні аспекти оцінювання стану розвитку туризму з точки зору економічної ефрективності здійснено у працях Галасюк С.С., Мігущенко Ю.В., Савіцької О.П., Савіцької Н.В.

Виділення невирішених раніше частин загальної проблеми. Зважаючи на різноманітність проведених досліджень у наукових літературних джерелах мало висвітлюеться методика рангових оцінок стану розвитку туристичної сорери за областями України.

Формулювання цілей статті. Вище сказане свідчить про доцільність проведення оцінювання конкурентоспроможності туристичної сдери областей України за такими етапами:

- визначити ключові елементи, котрі характеризують якісне обслуговування туристичної сорери;

- оцінити стан їх розвитку за областями України;

- відповідно до розрахованого субіндекус конкурентоспроможності туристичної сорери встановити рангові показники кожної із аналізованих областей.

Виклад основного матеріалу. Туризм у XXI столітті ознаменувався масовістю та ціновою доступністю. Це стало можливим завдяки багатьом чинникам - розвитку різних видів транспорту, медицини, засобів масової інформації, розширення номенклатури закладів гостинності, зростанню рівня освіченості та добробуту населення. Як вже вище зазначалось, туризм $е$ поліструктурним явищем, стан котрого залежить не лише від якісного рівня різного виду інфрастур, а й від різноманітності рекреаційних та історико - культурних ресурсів. Саме тому здійснюючи оцінювання конкурентоспроможності туристичної сорери регіонів України слід розраховувати субіндекс встановивши такі ключові елементи (див. форомула 1):

$$
\begin{gathered}
\mathrm{Qir}_{\mathrm{n}}=\left(\mathrm{Ati}_{\mathrm{n}}+\mathrm{Gti}_{\mathrm{n}}+\mathrm{Hi}_{\mathrm{n}}+\mathrm{IKt}_{\mathrm{n}}+\right. \\
\left.+\mathrm{Hr}_{\mathrm{n}}+\mathrm{Nr}_{\mathrm{n}}+\mathrm{Cr}_{\mathrm{n}}+\mathrm{Hor}_{\mathrm{n}}\right) / 8
\end{gathered}
$$

де $\mathrm{Qir}_{n}$ - субіндекс конкурентоспроможності сорери туризму за областями;

$\mathrm{Ati}_{\mathrm{n}}$ - показник якості інфраструктури повітряного транспорту;

Gti - показник якості індрраструктури наземного транспорту (залізничний транспорт та автобусний);

$\mathrm{Hi}_{\mathrm{n}}$ - показник якості інфрраструктури проживання;

$\mathrm{IKt}_{\mathrm{n}}$ - показник якості інфрраструктури інформаційно-комунікативних технологій;

$\mathrm{Nr}_{\mathrm{n}}$ - показник, що характеризуе природні ресурси;

$\mathrm{Cr}_{\mathrm{n}}$ - показник, що характеризуе культурні ресурси;

Hor $_{n}$ - показник, що характеризуе інфраструктуру харчування.

Отже, для знаходження рівня конкурентоспроможності туристичної сфрери за областями нашої держави, необхідно розрахувати співвідношення для кожного окремо взятого показника, котрі розраховуватимуться аналогічно, приклад котрого наведено для авіаційного транспорту (див. форорула 2):

$$
\operatorname{Ati}_{\mathrm{n}}=\text { Atic }_{\mathrm{n}} / \text { Atil; }
$$

де Atic $_{n}$ - відношення загального пасажирообороту окремо взятого міжнародного аеропорту

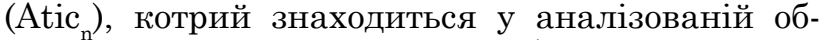
ласті до загального пасажирообороту аеропортів в Україні (Atil). Дані розраховуються відповідно до статистичних даних Міністерства інфраструктури України [6].

Відповідно показник конкурентоспроможності транспортного сполучення розраховуватиметься:

$$
\mathrm{Gti}=\mathrm{Gtic}_{\mathrm{n}} / \mathrm{Gtil}
$$

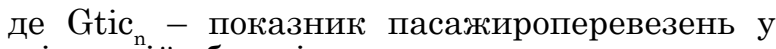
аналізованій області, млн. пас;

Gtil - показник пасажироперевезень у країні, млн. пас.

Забезпеченість туристів закладами розміщення характеризуватиметься:

$$
\mathrm{Hi}=\mathrm{Hic}_{\mathrm{n}} / \mathrm{Hil}
$$

де $\mathrm{Hic}_{\mathrm{n}}$ - показник кількості об'єктів розміщення у аналізованій області (готелі і ін.), од.;

Hil - показник кількості об'єктів розміщення у країні (готелі і ін.), од.

Якість інформаційно-комунікаційних послуг:

$$
\mathrm{IKt}=\mathrm{IKtc}_{\mathrm{n}} / \mathrm{IKtl} \text {; }
$$

де IKtc - інфрраструктура інформащійно-комунікаційних технологій, обсяг наданих послуг у аналізованій області, млн. грн.;

IKtl - інфрраструктура інфрормаційно-комунікаційних технологій, обсяг наданих послуг загалом у країні, млн. грн.

Забезпеченість областей природними ресурсами:

$$
\mathrm{Nr}=\mathrm{Nrc}_{\mathrm{n}} / \mathrm{Nrl}
$$

де $\mathrm{Nrc}_{\mathrm{n}}$ - показник, що характеризуе природні ресурси країни, а саме кількість об'єктів природно заповідного фонду у аналізованій області, од.;

$\mathrm{Nrl}$ - показник що характеризуе природні ресурси країни, а саме кількість об'єктів природно заповідного фонду у країні, од.

Наявність історико-культурних пам'яток:

$$
\mathrm{Cr}=\mathrm{Crc}_{\mathrm{n}} / \mathrm{Crl} \text {; }
$$

де $\mathrm{Crc}_{\mathrm{n}}$ - показник, що характеризуе культурні ресурси аналізованої області, а саме пам'ятки національного, міжнародного значення, од.;

Crl - показник, що характеризуе культурні ресурси країни, а саме пам'ятки національного, міжнародного значення, од.

Забезпеченість закладами харчування:

$$
\operatorname{Ir}=\operatorname{Irc}_{\mathrm{n}} / \operatorname{Irl}
$$

де $\operatorname{Irc}$ - показник, що характеризуе кількість закладів харчування у аналізованій області, од.;

Irc - показник, що характеризує загальну кількість закладів харчування у державі, од.

Наведена нами методика оцінювання конкурентоспроможності туристичної сфрери за областями пропонує прийняти межі субіндексу від 0,01 до 0,1. Де значення субіндексу менше 0,05 - характеризуватиме конкурентоспроможність туристичної сорери у межах країни, як низьку. Показник субіндексу на рівні від 0,051 до 0,1 - характеризуватиме конкурентоспроможність туристичної сорери області як середню. Та отриманий рівень показника від 0,1 - характеризуватиме рівень конкурентоспроможності туристичної сфери як високий. 
量

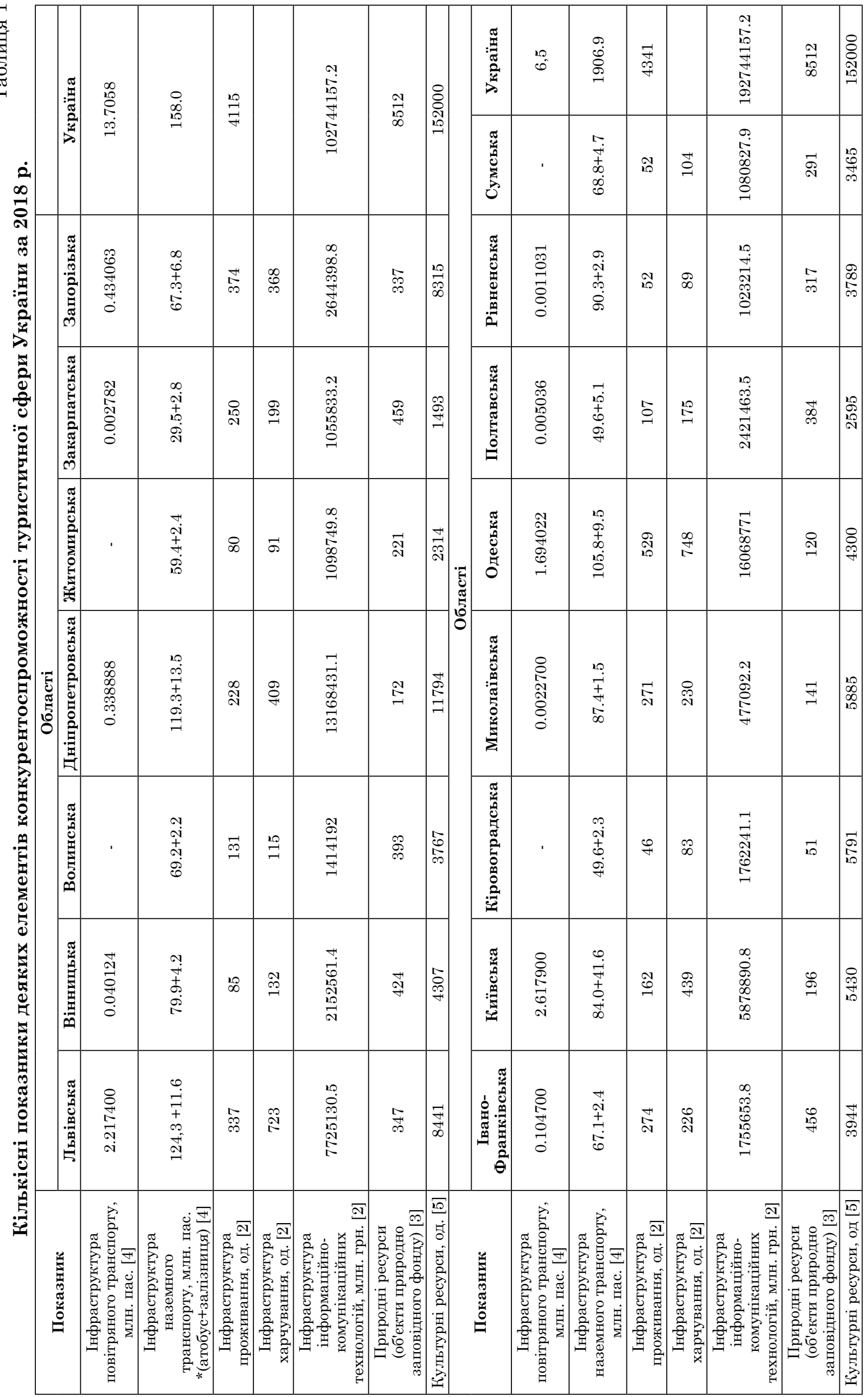


息

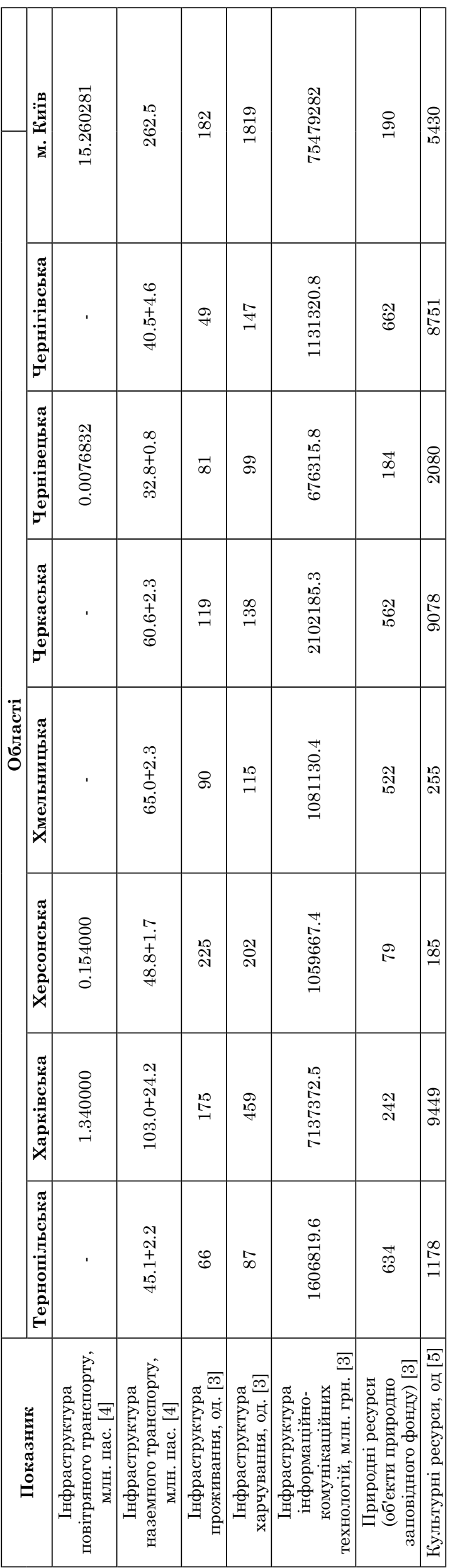

Кількісні значення вище вказаних ключових показників конкурентоспроможності туристичної сфери за областями України наведемо у таблиці 1.Дані відображені у таблиці 1 свідчать:

1) в Україні діє лише два аеропорти, котрі в змозі забезпечити високу пропускну здатність пасажиропотоку: «Бориспіль», котрий має в наявності дві смуги (в 4000 м та 3500 м), та «ім. Данила Галицького» (м. Львів, 3305 м). Решта аеропортів через недосконалу логістику, застарілу матеріально-технічну базу та недостатню величину злітно-посадкової смуги не в змозі забезпечити високу техніко-економічну ефективність. Сюди належать: аеропорт «Київ» (довжиною смуги у 1800 м), «Тернопіль» (2000 м), «Вінниця» (2500 м), «Дніпропетровськ» (2841 м), «Житомир» $(2500$ м), «Запоріжжя» (2502 м), «Івано-Франківськ» (2507 м), «Кривий Ріг» (2500 м), «Лиманське» (м. Одеса, 2503 м), «Одеса» (2799 м), «Полтава» (2600 м), «Рівне» (2626 м), «Ужгород» (2038 м), «Харків» (2500 м), «Херсон» (2500 м), «Черкаси» $(2500$ м) та «Чернівці (2200 м). Так, для прикладу, у Німеччині діє 539 аеропортів міжнародного та регіонального рівня [7]. Аеропорт «Схіпгол» в Нідерландах у своєму розпорядженні має шість злітно-посадкових смуг, п'ять із котрих мають довжину більше 3400 м. Річний пасажиропотік котрого у 2019 році до пандемії COVID-19 становив 71,7 млн. осіб [6].

2) кількісні дані автобусного та залізничного пасажирообороту свідчать, що більшість українців надае перевагу автомобільному. Низька розгалуженість залізничних колій (22,3 тис. км) та незадовільний стан рухомого складу робить даний вид транспорту непривабливим. В Україні 2019 році було перевезено 138,9 млн. осіб на противагу 1160 млн. осіб у Німеччині [7]. Найпопулярнішими вітчизняними напрямами є: Одеса (перевезено 9,5 млн. осіб у 2019 році), Львів (11,6 млн. осіб), Дніпропетровськ (13,5 млн. осіб), Київ (41,6 млн. осіб), Харків (24,2 млн. осіб).

3) у наведеній методиці оцінювання конкурентоспроможності туристичної сфери за областями України було б доцільно врахувати кількість осіб із вищою освітою, але нажаль обласні статистичні управління та державне управління статистики не вказують таких даних. А представлення даних про кількість осіб котрі навчаються у ВНЗ за областями України $є$ не репрезентативним, адже у такі міста як Львів, Харків, Київ з'їжджаються студенти із усієї України. Так за даними державного управляння статистики України в нашій державі проживае 5,522 млн. осіб із вищою освітою. Станом на 2020 рік у вищих навчальних закладах навчаеться 1,266121 млн. осіб. Найбільше студентів у Львівській (105,084 тис. осіб), Одеській (85,298 тис. осіб), Харківській $(150,385$ тис. осіб), Дніпропетровській $(89,577$ тис. осіб) областях. У Киеві вищу освіту здобувае 324,248 тис. осіб [3]. Україна посідае 45 місце у світі за рівнем освіченості населення і лише 6\% ВВП витрачае на забезпечення населення освітніми послугами.

4) Інфраструктура проживання та харчування в усіх областях України за останні десятки років динамічно зростала. Беззаперечними лідерами за їх кількістю є Львів, Одеса, Київ, котрі попри суміжні галузі народного господарства мають розвинену туристичну сферу. Індустріальні 
міста - Дніпропетровськ, Запоріжжя, хоч і нарощують кількість закладів гостинності, але не маючи туристичної затребуваності не в змозі забезпечити їх фрінансово-економічну ерективність. Велика кількість закладів харчування в промислових обласних центрах зумовлена наявністю платоспроможного працездатного населення.

5) За роки незалежності площа природно-заповідного фонду України зросла більш ніж удвічі. У 2016 рощі до його складу входило понад 8 тисяч об'єктів загальною площею 3,3 мільйони га, що становило 6,05\% національної території. А саме: 19 природних та 5 біосферних заповідника, 49 національних природних парків, 45 регіональних ландшафтних парків, 3078 пам'яток природи, 2729 заказників, 616 ботанічних, зоологічних садів, дендропарків та парків-пам'яток садово-паркового мистецтва, 793 заповідних урочища. Попри це, площа природно-заповідного фонду в Україні $\epsilon$ недостатньою і залишаться значно меншою, ніж у більшості країн Свропи, де середній відсоток заповідності становить 15\% [3].

6) Сьогодні на державному обліку в Україні перебуває 152 тис. пам'яток культурно-історичної спадщини, із котрих 56 тис. - пам'ятки історії, 7 тис. - пам'ятки монументального мистецтва, 15 тис. - пам'ятки містобудування та архітектури. Відповідно до українського законодавства існуе вісім видів пам'яток [1]:

1. Археологічні.

2. Історичні.

3. Монументального мистецтва.

4. Архітектури.

5. Містобудування.

6. Садово-паркового мистецтва.

7. Ландшафртні.

8. Об'єкти науки і техніки.

В усіх областях України є значна кількість історико культурних пам'яток, котрі належать до різних епох. Найбільшою популярністю користуються архітектурні, котрі найкраще представлені у місті Львові, Одесі, Киеві. Про популярність цих міст свідчать значні туристичні потоки та кількість закладів туристичного обслуговування. Більшість українських областей не мо- жуть похвалитись привабливими з туристичної точки зору об'єктами, а часто за наявності таких, перешкодами їх популяризації є відсутність розвиненої транспортної інформаційної інфраструктури, значна територіальна віддаленість і т.п.

Відповідно до статистичних даних представлених у таблиці 1 проведемо розрахунок субіндексу конкурентоспроможності туристичної сфрери за областями України відповідно до прикладу поданого у таблиці 2.

Агреговані показники субіндексу для решти регіонів нашої держави відобразимо у таблиці 3 .

Субіндекс конкурентоспроможності Львівської області розрахуємо за фрормулою 1:

$$
\text { Qirn }=0.161+0.229+0.081+
$$

$+0.100+0.075+0.040+0.055=0.1064$

Відповідно отриманий нами показник свідчить, що Львівщина серед решти регіонів України є високою конкурентоспроможною у порівнянні із рештою областей (див. рис. 1).

Відповідно до розрахованих значень високою конкурентоспроможністю туристичної сорери в Україні відзначаються лише Львівська область $(0,1064)$ та місто Київ $(0,1594)$, середню демонструють Дніпропетровська (0,08387), Одеська $(0,08488)$, Київська $(0,0937)$, Харківська $(0,0720)$ та Запорізька $(0,05982)$ області (див рис. 1$)$.

Нажаль решта областей не в змозі задовольнити комплексні потреби туристів. Адже, як свідчить практика наявність історико-культурних об’єктів, чи унікальних природних рекреаційних ресурсів не гарантує затребуваність туристичної дестинації на ринку. Інколи банальна інфраструктура розваг, гостинності, проживання, харчування, транспортна доступність може вплинути на туристичну привабливість місцевості.

Висновки та перспективи подальших досліджень. Нажаль за роки незалежності Україна не зуміла посісти достойне місце серед решти Свропейських країн у туристичній сорері. Відстаючи не лише у кількості туристичних прибуттів, наша держава не змогла створити внутрішній конкурентоспроможний туристичний продукт, котрий був би здатний згенерувати внутрішній

Алгоритм розрахунку показника конкурентоспроможності сфери туризму на прикладі Львівської області (станом на 2018 рік)

\begin{tabular}{|l|c|c|c|c|}
\hline \multicolumn{1}{|c|}{ Показник } & $\begin{array}{c}\text { Львівська } \\
\text { область }\end{array}$ & Україна & $\begin{array}{c}\text { Розрахунок } \\
\text { показника } \\
\text { індексу }\end{array}$ & $\begin{array}{c}\text { Показник } \\
\text { індексу }\end{array}$ \\
\hline $\begin{array}{l}\text { Iнфраструктура повітряного } \\
\text { транспорту, млн. пас. }\end{array}$ & 2.2174 & 13.7058 & Ati = Atic /Atil & 0.161 \\
\hline $\begin{array}{l}\text { Iнфраструктура наземного } \\
\text { транспорту, млн. пас. }\end{array}$ & $124.3+11.6$ & 158 & Gt = Gtic/Gtil & 0.229 \\
\hline $\begin{array}{l}\text { Інфраструктура проживання, } \\
\text { к-ть закладів, од. }\end{array}$ & 337 & 4115 & Hi = Hic /Hil & 0.081 \\
\hline $\begin{array}{l}\text { Iнфраструктура харчування, } \\
\text { к-ть закладів, од. }\end{array}$ & 723 & 7197 & Ir = Irc/Irtc & 0.100 \\
\hline $\begin{array}{l}\text { Інфраструктура інформаційно- } \\
\text { конмунікаційних технологій, } \\
\text { обсяг наданих послуг, млн. грн. }\end{array}$ & 7725131 & 102744157.2 & IKt = IKtc/IKtl & 0.075 \\
\hline $\begin{array}{l}\text { Природні ресурси (об'єкти } \\
\text { природно заповідного фронду), од. }\end{array}$ & 347 & 8512 & Nr = Nrc /Nrl & 0.040 \\
\hline $\begin{array}{l}\text { Культурні ресурси (пам'ятки } \\
\text { національного значення), од. }\end{array}$ & 8441 & 152000 & Cr = Crc/Crl & 0.055 \\
\hline
\end{tabular}




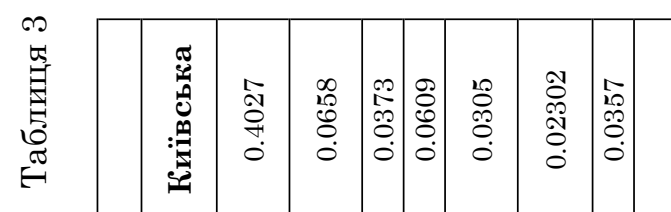

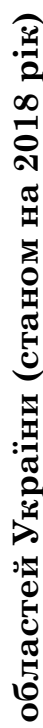



⿷匚⿳丨コ丨

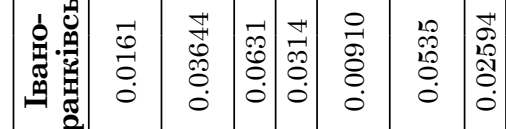

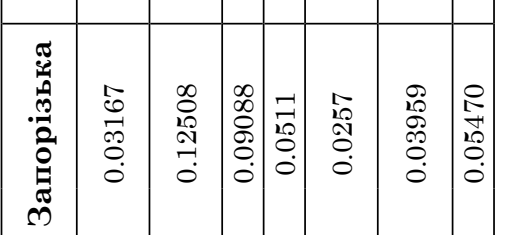

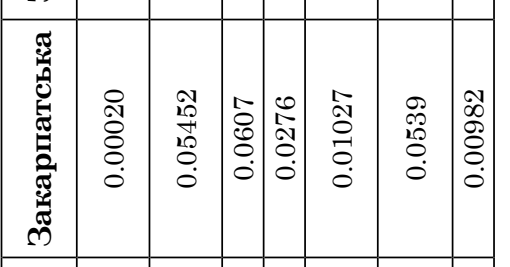

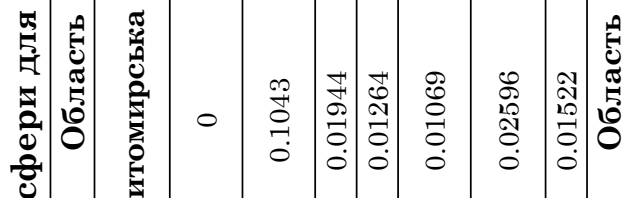

|

空



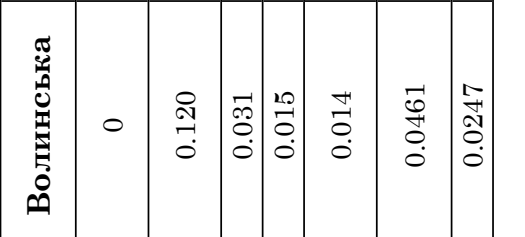

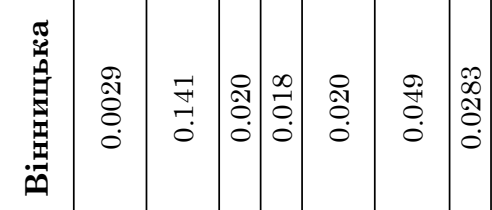

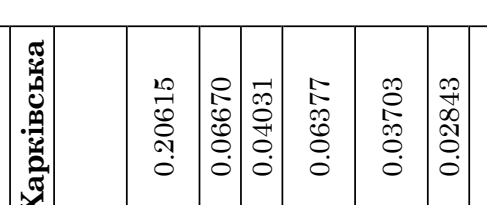

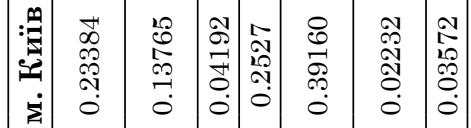

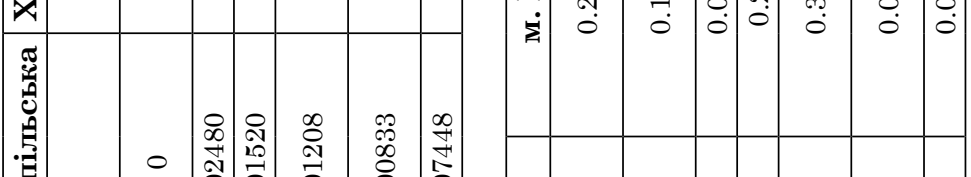

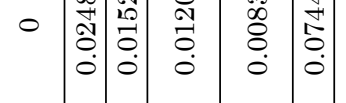

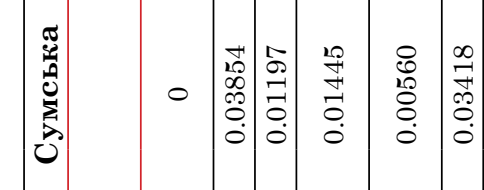
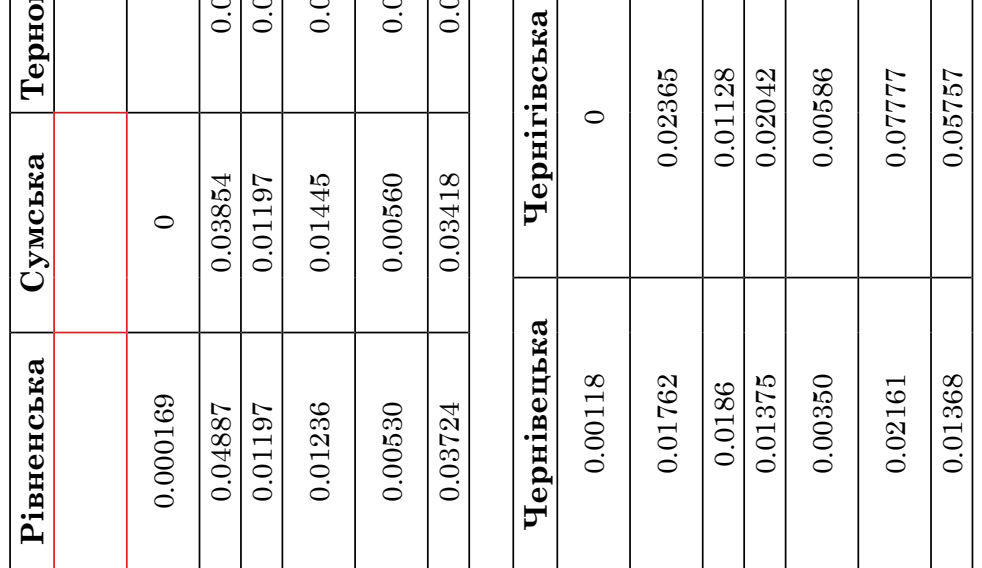

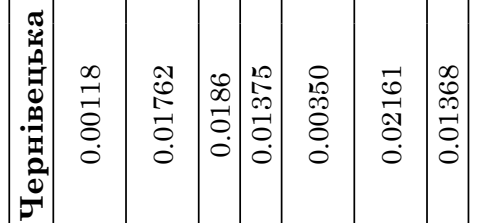

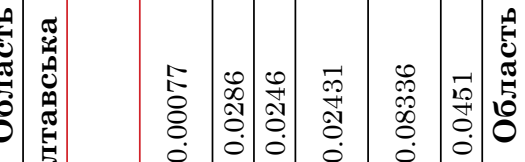

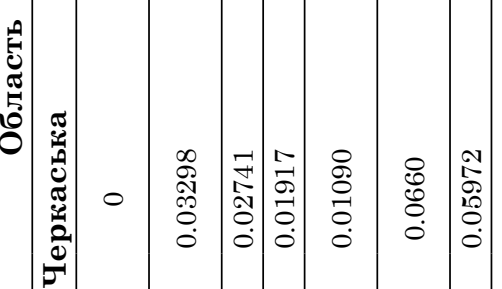

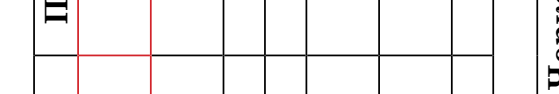

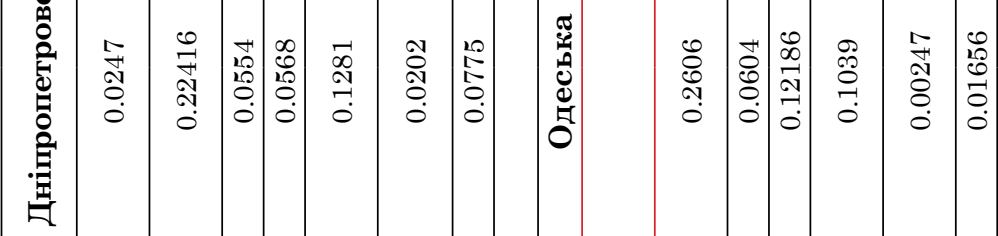

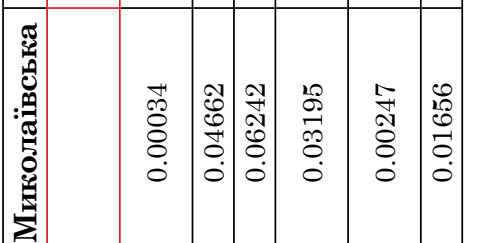

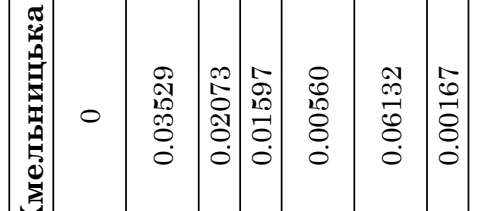

要

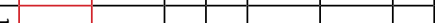

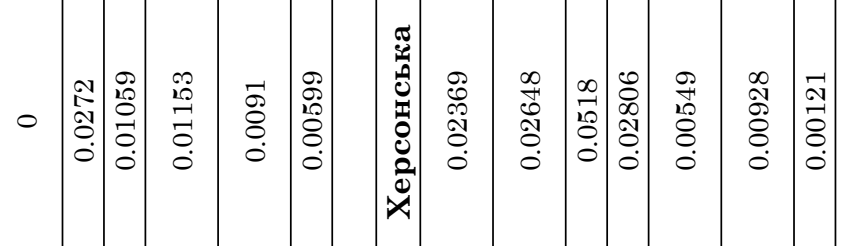

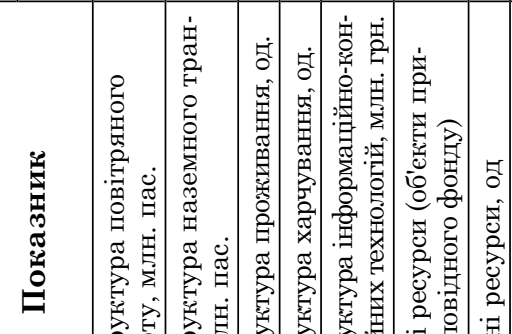

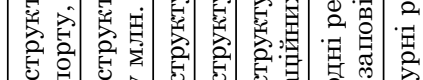

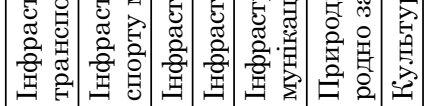
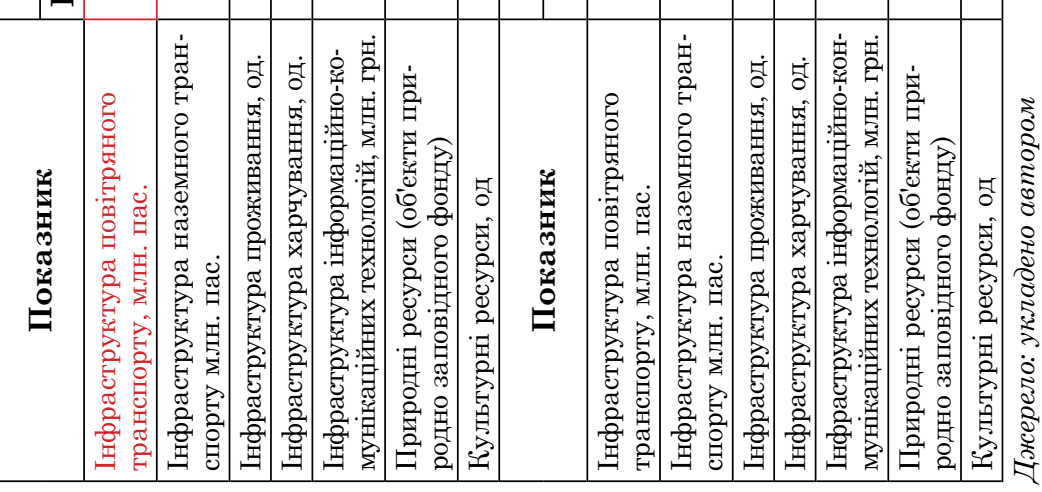


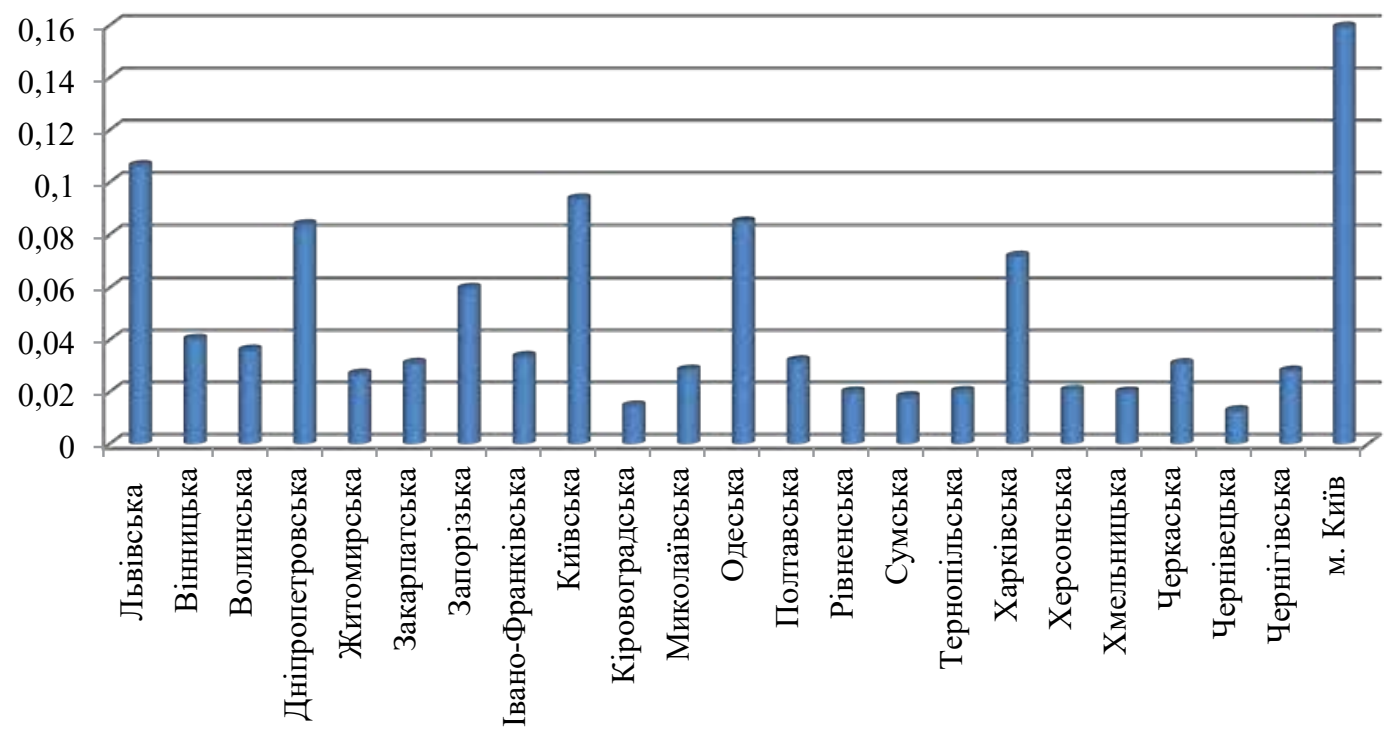

Рис. 1. Субіндекс конкурентоспроможності туристичної сфери областей України

туристичний рух. Адже, виїзні туристичні потоки лише послаблюють економіку країни, вивозячи готівкову валюту закордон. Наявні гірськолижні курорти - Буковель, Драгобрат, Плай і ін. не в стані конкурувати із польськими Татрами, котрі в рази перевищують рівень комдрортності перебування туристів, якості обслуговування за нижчим ціновим паритетом ніж вітчизняні. Ясне ж діло ми не вказуватимемо на курорти Швейцарії, Австрії, Італії - країни котрі за індексом конкурентоспроможності подорожей i туризму на світовому ринку свого часу посідали першість. Але країни, котрі у 90-х були більш-менш у рівних стартових умовах за тридцять років зуміли наростити вагомість у світі туризму.

Сьогодні за туристичними потоками Україну, із країн колишнього соцтабору, випереджають не лише Польща, а й Литва, Латвія, Хорватія, Словаччина. Хоча в умовах пандемії COVID-19 туризм зазнає значних втрат, але ці країни зуміли диверсифікувати структуру формування ВВП, чим забезпечили собі різні джерела доходів.

\section{Список літератури:}

1. Закон України «Про охорону культурної спадщини». URL: https://zakon.rada.gov.ua/laws/show/1805-14

2. Державна служба статистики України. URL: http://www.ukrstat.gov.ua/

3. Міністерство екології та природних ресурсів України. URL: http://pzf.menr.gov.ua/

4. Міністерство інфраструктури України. URL: https://mtu.gov.ua/content/statistichni-dani-pro-ukrainskizaliznici.html

5. Урядовий портал. Сдиний веб - портал органів виконавчаої влади України. Перелік об'єктів культурної спадщини національного значення, які заносяться до Державного реестру нерухомих пам'яток України. URL: https://www.kmu.gov.ua/npas/239966145

6. Schiphol investeert in kwaliteit en innovatie. URL: https://nieuws.schiphol.nl/jaarcijfers-2019/

7. Statistische Bundesamt. URL: https://www.destatis.de/EN/eu2020/_node.html

8. Travel \& Tourism Competitiveness Report 2015. URL: www.weforum.org.docs/WEF_TTCReport_2015.pdf

\section{References:}

1. The Verkhovna Rada of Ukraine (2000) The Law of Ukraine "On the protection of cultural heritage". Available at: https://zakon.rada.gov.ua/laws/show/1805-14 (accessed 03 December 2020).

2. State Statistics Service of Ukraine (2018). Available at: http://www.ukrstat.gov.ua/ (accessed 03 December 2020).

3. Ministry of Ecology and Natural Resources of Ukraine (2020) "Nature reserve fund of Ukraine". Available at: http://pzf.menr.gov.ua/ (accessed 03 December 2020).

4. Ministry of Infrastructure of Ukraine (2020) "Railways". Available at: https://mtu.gov.ua/content/statistichnidani-pro-ukrainski-zaliznici.html (accessed 03 December 2020).

5. Government portal. The only web portal of the executive authorities of Ukraine. The list of cultural heritage sites of national importance, which are entered in the State Register of Immovable Monuments of Ukraine (2020). Available at: https://www.kmu.gov.ua/npas/239966145 (accessed 03 December 2020).

6. Schiphol (2019) „Schiphol invests in quality and innovation”. Available at: https://nieuws.schiphol.nl/ jaarcijfers-2019/ (accessed 09 December 2020).

7. Statistische Bundesamt (2020) "German Presidency of the Council Working Party on Statistics". Available at: https://www.destatis.de/EN/eu2020/_node.html (accessed 09 December 2020).

8. Travel \& Tourism Competitiveness Report 2019. "Travel and Tourism at a Tipping Point". Available at: http://www3.weforum.org/docs/WEF_TTCR_2019.pdf (accessed 02 December 2020). 